\title{
Study Regarding the Surface State of Composite Resins After Finishing and Polishing Using Different Systems
}

\author{
SORIN ANDRIAN, GIANINA IOVAN, GALINA PANCU, CLAUDIU TOPOLICEANU, ANDREI GEORGESCU, SIMONA STOLERIU*, \\ IONUT TARABOANTA, IRINA NICA \\ Grigore T. Popa University of Medicine and Pharmacy lasi, Faculty of Dental Medicine, 16 Universitatii Str., 700115, Iasi, \\ Romania
}

\begin{abstract}
The aim of this study was to evaluate the influence of different finishing and polishing systems and of composite resins structure on surface state of the restoration. Cylindrical samples from two different composite resins (Filtek Z 550 and Filtek Z 250, 3M ESPE) were obtained. In group 1 the samples were not finished and polished. In groups 2-4 the samples were submitted to finishing procedure using two tungsten carbide burs, then polished using three different polishing systems: three steps diamond abrasive polishers (Kenda CGI, Lichtenstein) - group 2, one step silicon carbide abrasive particles brush (Occlubrush, KerrHawe $S A$, Switzerland) - group 3 and two steps Sof-Lex spiral wheels (3M ESPE) - group 4. Half of the samples in each group were subjected to surface microstructure evaluation using a scanning electron mycroscope. The other half of the samples was subjected to surface state assessment using profilometery. All the investigated finishing and polishing systems leaded to increased surface roughness when compared to the roughness of composite resins placed in direct contact to celluloid clear matrix. The surface roughness of both microfilled-hybrid and nanofilled-hybrid composite resins finished and polished with different systems were influenced mostly by the polishing system and less by the composite resin structure.
\end{abstract}

Keywords: composite resins, finishing, polishing, SEM, profilometry

The most frequently used composite resins for direct restorations can be included in one of these categories: high viscosity (condensable) and low viscosity (flowable) [1]. The high consistency (density) of the composite resins relies on high inorganic particle loading which ensure high wear resistance and optimal physical properties. Irrespective of the cavity topography, the restorative materials should have a smooth surface in order to prevent the biofilm retention and external staining $[2,3]$. Theoretically, this goal might be achieved by using finishing and polishing systems of which efficiency is related to material composition (organic partlinorganic part ratio) [4]. Practically, is very difficult to obtain a perfectly smooth surface because the organic matrix and the inorganic fillers have different hardness and consequently different wear resistance [5-12].

In the clinical step of functional adjustment of the restoration sometimes is necessary to remove the excess of restorative material or to recontour the margins of the restoration by finishing procedure. For a finishing system the flexibility of abrasive particles support, the particles hardness and size can also influence the surface state of the restoration $[2,13]$.

The aim of this study was to evaluate the influence of different finishing and polishing systems and of composite resins structure and composition on surface state of the restoration. The qualitative evaluation of surface microstructure was determined by scanning electron microscopy (SEM) and the quantitative evaluation by assessing the surface roughness using profilometry.

\section{Experimental part}

Two different composite resins were chosen for this study: Filtek Z250 (3M ESPE, St. Paul, MN, USA) and Filtek Z550 (3M ESPE, St. Paul, MN, USA). Filtek Z250 is a universal, microfilled-hybrid composite material. The filler consists in zirconia and silica particles with the size varying from 0.01 to $3.5 \mu \mathrm{m}$ and zirconia/silica clusters having $0.6-1.4 \mu \mathrm{m}$ with an average particle size of $0.6 \mu \mathrm{m}$. The inorganic filler loading is $60 \%$ by volume and $84.5 \%$ by weight. Organic matrix is represented by a mixture of Bis-GMA, Bis-EMA, TEGDMA and UDMA. Filtek Z550 is a nanohybrid, universal composite resin with high viscosity. In chemical composition the organic matrix is represented by BIS-GMA, UDMA, BIS-EMA, PEGDMA and TEGDMA. The inorganic part is a combination of non-agglomerated/non aggregated silica particles having $20 \mathrm{~nm}$ and modified particles of silica and zyrconia having $3 \mathrm{~mm}$. Inorganic part represent $82 \%$ by weight and $68 \%$ by volume. The inorganic particles technology is a unique procedure of hybridization starting from the basic structure of Filtek Z250 composite resin with the purpose of obtaining a nanohybrid composite resin with the same mechanical resistance due to nanoparticles or nanoclusters, but more esthetic. Producers claimed that it is an unsticky material, easy to handle and to be finished and polished. Details about composite resins type, producer and chemical composition are presented in table 1.

Forty cylindrical samples of each material having $5 \mathrm{~mm}$ in diameter and $2 \mathrm{~mm}$ in hight were obtained by condensing the composite resins into plastic molds. The molds were placed in direct contact with a clear celluloid matrix between two glass slabs in order to obtain flat surfaces of the sample. Composite resins were lightcured 40 seconds through the glass slabs using a LED curing unit (Optilight LD MAX - Gnatus) having a wavelength of 470 $480 \mathrm{~nm}$ and a lightintensity of $600 \mathrm{~mW} / \mathrm{cm}^{2}$. After removing from the molds, the samples were randomly and equaly asigned to 4 groups.

In control group (group 1) the samples were not finished and polished. In group 2 the samples were submitted to finishing procedure using two tungsten carbide burs: H135Q (batch 906561) for gross finishing and H135UF

\footnotetext{
* email: stoleriu_simona@yahoo.com
} 
Table 1

DETAILS ABOUT TESTED MATERIALS

\begin{tabular}{|c|c|c|c|c|c|}
\hline \multirow[t]{3}{*}{ Material } & \multirow{3}{*}{$\begin{array}{c}\text { Manufacturer/Type/B } \\
\text { atch No./Shade }\end{array}$} & \multicolumn{4}{|c|}{ Chemical composition } \\
\hline & & \multirow[t]{2}{*}{ Matrix } & \multicolumn{3}{|c|}{$\begin{array}{c}\text { Filler } \\
\end{array}$} \\
\hline & & & Type & Size & Load \\
\hline $\begin{array}{l}\text { Filtek Z250 } \\
\text { Universal } \\
\text { Restorative }\end{array}$ & $\begin{array}{l}3 \mathrm{M} \\
\text { ESPE,St.Paul,MN,USA } \\
\text { Microhybrid } \\
\text { N797790/Enamel A2 }\end{array}$ & $\begin{array}{l}\text { Bis-GMA, } \\
\text { Bis- } \\
\text { EMATEG } \\
\text { DMA } \\
\text { UDMA }\end{array}$ & zirconia and silica particles & $\begin{array}{l}0.01-3.5 \mu \mathrm{m} \\
\text { average } \\
\text { particle size } \\
\text { of } 0.6 \mu \mathrm{m}\end{array}$ & $\begin{array}{l}84,5 \text { wt } \% \\
60 \text { vol } \%\end{array}$ \\
\hline $\begin{array}{l}\text { Filtek Z550 } \\
\text { Universal } \\
\text { Restorative }\end{array}$ & $\begin{array}{l}3 \mathrm{M} \\
\text { ESPE,St.Paul,MN,USA } \\
\text { Nanohybrid } \\
\text { N575623/Enamel A2 }\end{array}$ & $\begin{array}{l}\text { Bis-GMA, } \\
\text { UDMA, } \\
\text { Bis-EMA, } \\
\text { PEGDMA } \\
\text { TEGDMA }\end{array}$ & $\begin{array}{c}\text { Non-agglomerated } \\
\text { non-aggregated silica } \\
\text { particles }\end{array}$ & $3 \mu \mathrm{m}$ & $\begin{array}{l}82 \mathrm{wt} \% \\
68 \mathrm{vol} \%\end{array}$ \\
\hline $\begin{array}{l}\text { Bis-GMA: B } \\
\text { Triethylenegly } \\
\text { dimethacrylate }\end{array}$ & $\begin{array}{l}\text { enol A diglycidyl } \\
\text { limethacrylate; bis-EMA }\end{array}$ & $\begin{array}{l}\text { er dimeth } \\
\text { ethoxylated }\end{array}$ & $\begin{array}{l}\text { ylate; UDMA:urethane di } \\
\text { sphenol-A dimethacrylate; } \mathrm{PE}\end{array}$ & $\begin{array}{l}\text { thacrylate; } \\
\text { DMA: poly }\end{array}$ & $\begin{array}{l}\text { EGDMA: } \\
\text { ene glycol }\end{array}$ \\
\hline
\end{tabular}

(batch 903481) (ISO 500314166031014) for ultrafine finishing and then polished using three steps point polishers (Kenda CGI, Lichtenstein) in these sequence: white (coarse) (ISO 638204243533050), green (medium) (ISO 638204243523050) and pink (ultrafine) (ISO 638204243493050). Each finishing bur acted 30 seconds at20.000 revolutions per minute (rpm) under water cooling only in clockwise direction. Polishing procedure was performed at $7500 \mathrm{rpm}$, under water cooling, each polisher being used a single time for $30 \mathrm{~s}$. In group 3 the samples were submitted to finishing procedure using tungsten carbide burs $\mathrm{H} 135 \mathrm{Q}$ and H135UF and then polished in one step using silicon carbide abrasive particles brushOcclubrush (KerrHawe SA, Switzerland). Small cup brushes were used for polishing for 30 seconds at $5000 \mathrm{rpm}$. In group 4 the samples were submitted to finishing procedure using tungsten carbide burs H135Q and H135UF and then polished in two steps using beige and white Sof-Lex spiral wheels for finishing and polishing (3M ESPE). The spirals are made of a thermoplastic elastomer impregnated with aluminium oxide particles. During polishing procedure the spiral wheels were used only once for each sample for 30 s at a speed of $20.000 \mathrm{rpm}$ and with no water spraying. The samples were than cleaned using distilled water and air dryed.

Half of the samples in each group were subjected to surface microstructure evaluation using a scanning electron mycroscope VEGA II LSH TESCAN (Cech Republic). Images for each sample were obtained at four different magniffication: 500, 1000, 2000 and 5000. Only the images at 500 and 2000 magnification were chosen to be evaluated due to their increased accuracy. The other half of the samples was subjected to surface state assessment using a profilometer TAYLOR HOBSONSurtronic 25 (AMETEK Inc.Pennsylvania, USA). Five individual determinations were made for each sample. $R_{\text {}}$ parameter was registered for each determination and the mean value (the average of five determinations) of the parameter was reported for all the samples.

\section{Results and discussions}

SEM microstructural images at different magification for Filtek Z550 samples in groups 1-4 are presented in figure 1. Samples from group 1 presented shallow microgaps at 500 magnification. At higher magnification (2000x) aggregations of silica and zirconium oxide particles having variable sizes became visible. Also, non-aggregated, lower sized particles located between the clusters were identified. In group 2 distinct micro-channels have been identified. Their width varied from 5 to $20 \mu \mathrm{m}$ and the distance between two successive micro-channels varied from $20 \mu \mathrm{m}$ to $50 \mu \mathrm{m}$. In group 3 micro-channels having lower width than in group $2(2-5 \mathrm{~mm})$ were present. The mean distance between two successive micro-channels was $20 \mu \mathrm{m}$. In group 4 rare and shallow micro-channels were identified. Clusters having higher sizes became visible after removing very fine particles from the surface.

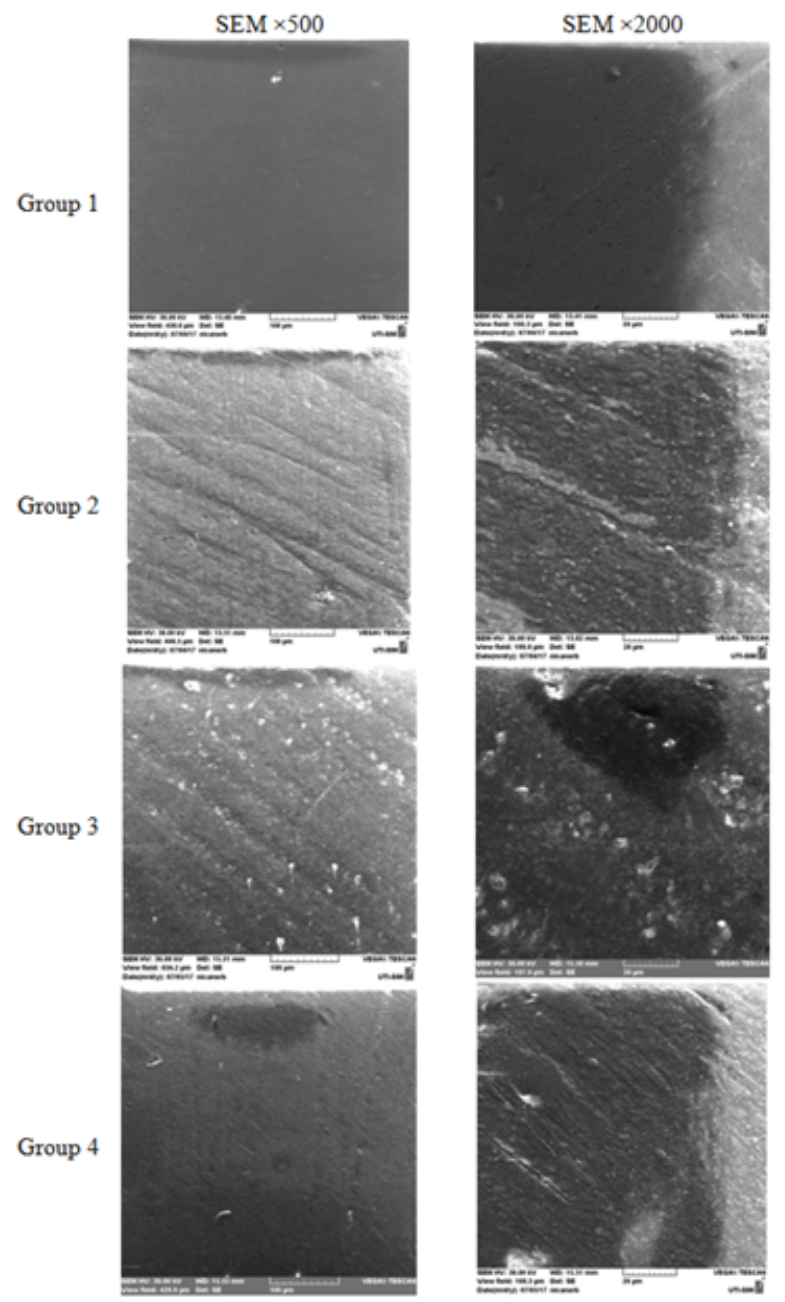

Fig.1. SEM microstructural images at different magification for Filtek Z550 samples in groups 1-4 
Microstructural images at different magification for Filtek Z250 samples in groups 1-4 are presented in figure 2. In group 1 the samples presented very shallow microgaps at 500 magnification, but at higher magnification (2000x) distinct aggregations of the filler particles became visible. In group 2 many micro-channels having a mean width of $5 \mu \mathrm{m}$ have been identified. The distance between two successive micro-channels varied from 5 to $10 \mu \mathrm{m}$. In group 3 very fine scratches were present. In group 4 many narrow micro-channels have been identified. Also, clusters having higher sizes became visible on the surface layer.

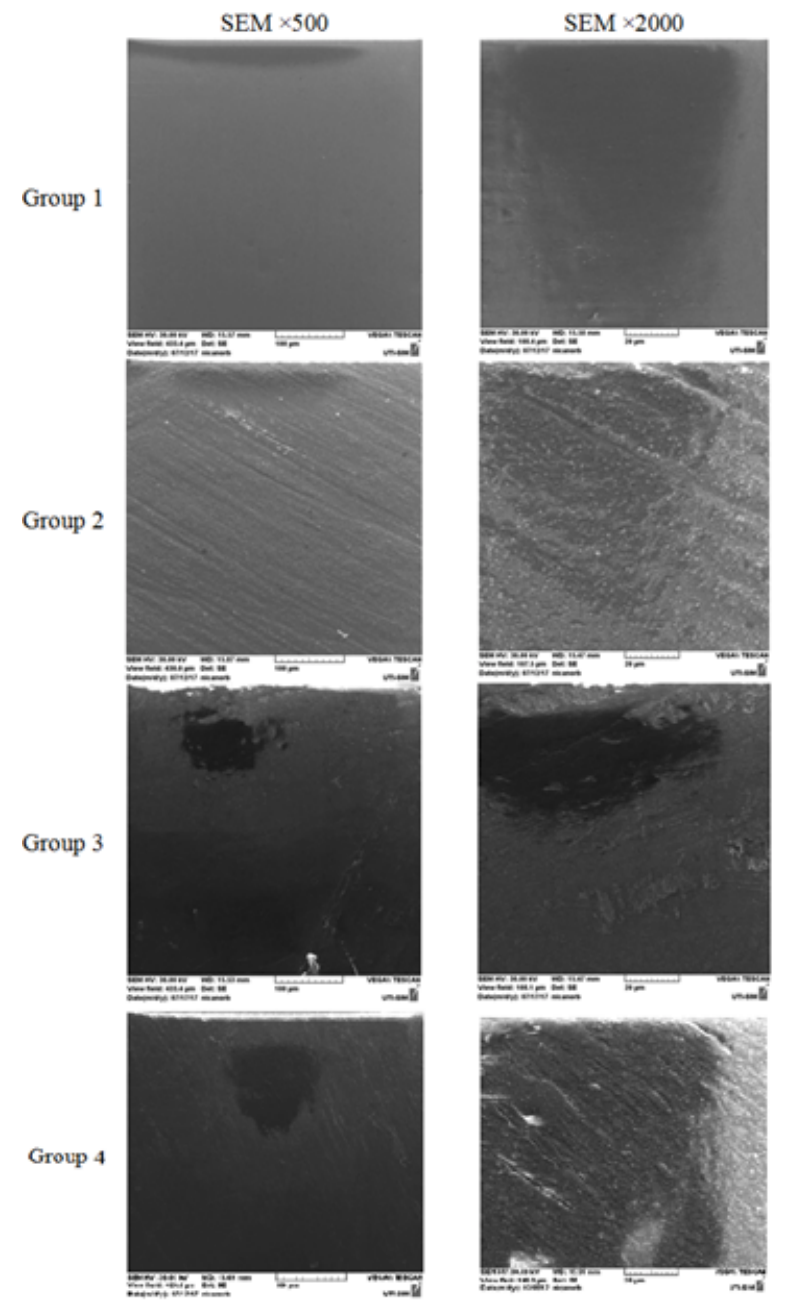

Fig. 2. SEM microstructural images at different magification for Filtek Z250 samples in groups 1-4

The mean $\mathrm{R}$ values in groups 1-4 for Filtek Z550 are presented in table 2. In group $2 \mathrm{R}$ a values have increased 7 times when compared to group $1 .{ }^{\text {a }}$ Also in group 3 increased values of $R$ were recorded (of 9.5 times) when compare to control group. When compared to group $2, R_{a}$ values in group 3 were 1.35 higher. In group $4 R_{a}$ values were also increased when compared to control group (of 3.75 times), but they were much lower when compared to groups 2 and 3. The mean $R_{a}$ values in groups 1-4 for Filtek Z250 are also presented in table 1 . In group $2 \mathrm{R}_{\text {a }}$ values have increased 11.5 times when compared to group 1. Also in group 3 increased values of $R$ were recorded (of 8.5times) when compare to control group. When compared to group $2, R_{a}$ values in group 3 were 1.35 higher. In group $4 R_{a}$ values were increased when compared to control group (of 11 times) and group 3 (of 1.29 time), but they were lower when compared to groups 2 (of 0.95 times).

Table 2

MEAN VALUES OF COMPOSITE RESIN SURFACE ROUGHNESS

$\left(R_{A}\right)$ IN GROUPS 1-4

\begin{tabular}{|l|c|c|}
\hline \multirow{2}{*}{} & \multicolumn{2}{|c|}{$\mathrm{R}_{\mathrm{a}}$ mean values $(\mu \mathrm{m}) \pm$ standard deviation } \\
\cline { 2 - 3 } & Filtek Z550 & Filtek Z250 \\
\hline Group 1 & $0.04 \pm 0.004$ & $0.02 \pm 0.002$ \\
\hline Group 2 & $0.38 \pm 0.021$ & $0.23 \pm 0.037$ \\
\hline Group 3 & $0.28 \pm 0.013$ & $0.17 \pm 0.018$ \\
\hline Group 4 & $0.15 \pm 0.002$ & $0.22 \pm 0.030$ \\
\hline
\end{tabular}

The lowest surface roughness was recorded when both composite resins were placed in direct contact with celluloid clear matrix, in the absence of finishing and polishing procedure. In the groups where finishing and polishing procedures were performed, the lowest mean surface roughness of Filtek Z 250 was recorded in group 4 and the highest in group 3. For Filtek Z 550 in the groups where finishing and polishing procedures were performed, the lowest mean surface roughness of Filtek Z 250 was recorded in group 2 and the highest in group 3.

The roughness values were statistically analyzed using Mann-Whitney test. Statisticaly significant results were recorded when compared the roughness values in groups 2-4 to group 1 for both composite resins (table 3). Also, statisticaly significant results were obtained when compared the results in group 2 and 3 to group 4 for Filtek Z250 and when compared the results in group 2 to groups 3 and 4. The results in group 3 for Filtek Z250 were not statisticaly significant when compared to group 4 (table 3).

For direct posterior restorations physical and mechanical properties of restorative material are essential for restoration longevity [14]. Material structure, by inorganic filler type, influences the handle and the surface final aspect after finishing and polishing. In in vitro studies other factors, as manual procedure to obtain the samples and the type of finishing and polishing systems (in one or more steps), might influence the surface state of the restoration [2]. In some studies was observed that multi-step finishing systems lead to smoother surface when compared to the systems in one or two steps [15]. On a contrary, other studies showed no statisticaly significant differences between one and two steps finishing systems [16].

In our study the lowest value of surface roughness was recorded when both composite resins were placed in direct contact with transparent matrix, in absence of finishing and polishing procedure. This is in accord with the results of other studies [17-19]. Nevertheless this surface layer photopolymerized in direct contact with the matrix has a higher content of organic matrix when compared with subjacent layer [20-22]. Removing this layer by finishing and polishing might determine increased the surface

\begin{tabular}{|l|l|l|l|l|l|l|}
\hline \multicolumn{7}{|c|}{ p values Mann-Whitney statistical test } \\
\hline & $\begin{array}{l}\text { Group1- } \\
\text { Group 2 }\end{array}$ & $\begin{array}{l}\text { Group1- } \\
\text { Group 3 }\end{array}$ & $\begin{array}{l}\text { Group1- } \\
\text { Group 4 }\end{array}$ & $\begin{array}{l}\text { Group2- } \\
\text { Group 3 }\end{array}$ & $\begin{array}{l}\text { Group2- } \\
\text { Group 4 }\end{array}$ & $\begin{array}{l}\text { Group3- } \\
\text { Group 4 }\end{array}$ \\
\hline $\begin{array}{l}\text { Filtek Z } \\
550\end{array}$ & 0.009 & 0.009 & 0.009 & 0.009 & 0.009 & 0.009 \\
\hline $\begin{array}{l}\text { Filtek Z } \\
250\end{array}$ & 0.009 & 0.009 & 0.009 & 0.016 & 0.016 & 0.917 \\
\hline
\end{tabular}

Table 3

MANN-WHITNEY STATISTICAL TEST RESULTS 
resistance $[23,24]$. Anatomic contour of the restoration is rarely obtained by using a celluloid matrix [25], so using finishing and polishing procedures, which remove the excess of material and give to the restoration the shape and the aspect similar to the tooth, become mandatory.

A finishing system should have abrasive particles with the hardness higher than inorganic particles in the composite resin in order to be efficient. If the hardness is lower, during finishing and polishing the superficial layer rich in resin are removed, filler particles being prominent in surface layer [26, 27]. Generaly, composite resins having lower size particles will have smoother surface after finishing and polishing when compared to composite resin having higher sizes particles [28]. New technique of grinding the particle untill nanoscale and integration of these partices as clusters in composite resin structure leaded to increased resistance and improved surface state [29]. Some studies estimated a mean roughness up to 1 $\mu \mathrm{m}$ of being acceptable for a surface that is visible smooth $[30,31]$. It was demonstrated that surface roughness between $0.7 \mu \mathrm{m}$ and $1.4 \mu \mathrm{m}$ did not prone to significantly bacterial plaque accumulation [32]. Other studies showed that most of commercial finishing and polishing systems lead to smooth composite surface, having the roughness of $0.02 \mu \mathrm{m}$ up to $0.56 \mu \mathrm{m}[33,34]$. In our study surface roughness varied between $0.15 \mu \mathrm{m}$ and $0.38 \mu \mathrm{m}$. We can consider the effect of finishing and polishing procedures applied on both composite resins that were investigated in this study of not having a noticeable clinical signification.

Another factor that might influence the surface state is represented by material intern structure (the shape, size and quantity of fillers) [30,34]. In our study there were recorded differences in surface roughness between the two analysed composite resins. Both materials have inorganic part higher than $50 \%$ by volume and represented by nano-sized non-agglomerated|non-aggregated silica particles and modified particles of silica and zyrconia dispersed between micro-sized clusters. The highest surface roughness was obtained when using finishing with carbide burs and three-step diamond abrasive polishers from Kenda. Probably, nano-sized particles in the resin extern layer were eliminated first in finishing procedure and clusters having higher sizes remained on the top of the surface. Previous studies showed that during finishing the smallest particles are removed together with a part of the organic matrix [35]. That is one reason why the fillers should be in tight contact one to each other and with organic matrix in order to protectit, which might lead to decreased polymerization shrinkage, increased wear resistance and optimal polishing [30]. For Filtek Z550 the lower surface roughness was recorded when Sof-Lex Spirals Finishing and Polishing Wheels were used. For Filtek Z250 finishing with carbide burs and polishing using Occlubrush leaded to the smoothest surface. This might be explained by the fact that silicone carbonate particles on the brush bristles have higher hardness when compare to aluminium oxyde. In our study different finishing and polishing systems determined different effects on the hybrid and nanofilledhybrid composite resins. This might lead to the conclusion that the surface state was not exclusively influenced by the material structure.

The complex structure of the resin surface can not be completely characterized only by profilometric analysis. Clinical performance can be predicted by correlation the surface roughness parameters and surface analysis using scanning electron microscopy which evaluates the agression of different finishing and polishing systems [30]. All finishing and polishing systems in the present study determined resin surface micro-channels coresponding to the scratches induced by the rotary instruments. Occlubrush polisher abraded evenly the fillers and the organic matrix and leaded to the smoothest Filtek Z 250 composite resin surface. Very rare and larger microchannels were observed when using this system when compared to diamond abrasive polishers from Kenda.

In order to avoid or to eliminate the dissimilar results obtained by using different finishing and polishing systems, the producers recommand the use of composite resin in conjunction with specific finishing system. Rarely these indication are sustained by clinical or laboratory studies which might confirm the efficiency of the systems used for specific materials. In current practice most of the time the steps to obtain a smooth surface are complicated and often unsatisfactory from efficiency/price point of view. Obtaining a smooth surface still remain a very important objective for directcomposite restorations. The correctness of this clinical step influences the longevity of the restoration.

The limitations of this study are represented by the lack of standardized forces applicated on the samples surface during finihing and polishing procedures and by flattening the samples surface in order to make the profilometric measurements. Clinicaly such flatten surfaces are considered an exception, most of the time tooth surfaces having a convexe or concave anatomy.

\section{Conclusions}

All the investigated finishing and polishing systems leaded to increased surface roughness when compared to the roughness of composite resins placed in direct contact to celluloid clear matrix. The surface roughness of both microfilled-hybrid and nanofilled-hybris composite resins finished and polished with different systems were influenced mostly by the polishing system and lesser by the composite resin structure.

\section{References}

1.BAROUDI, K., RODRIGUES, J.C., J. Clin. Diagn. Res., 9, no. 6, 2015, p.18.

2.STOLERIU, S., IOVAN, G., PANCU, G., NICA, I., ANDRIAN, S., Rom. J. Oral Rehabilit., 5, no. 3, 2013, p. 78.

3.ERDEMIR, U., SANCAKLI, H.S., YILDIZ, E., Eur. J. Dent.,6, 2012, p. 198.

4.TOFAN, N., PANCU, G., TOPOLICEANU, C., GEORGESCU, A., STOLERIU, S., ANDRIAN, S., Rev. Chim. (Bucharest), 66, no 12, 2015, p. 1974.

5.BALAN, A., SANDU, A.V., STOLERIU, S., PINTILICIUC, V.S., TOMA, V., Mat. Plast., 52, no.1, 2015, p. 55.

6.REIS, A.F., GIANNINI, M., LOVADINO, J.R., DOS SANTOS DIAS, C.T., Am. J. Dent., 15, 2002, p.193.

7.MATEI, M.N., EARAR, K., TRINCA, L.C., MARECI, D., FOTEA, L., PEPTU, C.A., BICA, C., Rev. Chim. (Bucharest), 67, no. 4, 2016, p. 800. 8.MARECI, D., EARAR, K., ZETU, I., BOLAT, G., CRIMU, C., ISTRATE, B., MUNTEANU, C., MATEL, M.N., Mat. Plast., 52, no. 2, 2015, p. 150. 9.MATEI, M.N., CHISCOP, I., EARAR, K., MOISEI, M., MARECI, D., TRINCA, L.C., STAN, T., MUNTEANU, C., PACURAR, M., ILIE, M., Rev. Chim. (Bucharest), 66, no 12, 2015, p. 2009.

10.EARAR, K., MATEI, M.N., SANDU, A.V., HRISTIAN, L., BEJ INARIU, C., SANDU, I.G., Mat. Plast., 52, no. 1, 2015, p. 98.

11.EARAR, K., CERGHIZAN, D., SANDU, A.V., MATEI, M.N., LEATA, R., SANDU, I.G., BEJ INARIU, C., COMAN, M., Mat. Plast., 52, no. 4, 2015, p. 487.

12.EARAR, K., BICA, C., CERGHIZAN, D., ILIE, M., Mat. Plast., 53, no. 3, 2016, p. 512.

13.YAP, A.U., LYE, K.W., Oper. Dent., 22, 1997, p. 260.

14.MORGAN, M., Pract. Proced. Aesthet. Dent., 16, 2004, p.211. 
15.JUNG, M., SEHR, K., KLIMEK, J., Oper Dent, 32, 2007, p. 45.

16.YAP, A.U., YAP, S.H., TEO, C.K., NG, J . ., Oper. Dent., 29, no. 1, 2004, p.100.

17.SARAC, D., SARAC, Y.S., KULUNK, S., URAL, C., KULUNK, T., J. Prosthet. Dent., 96, no.1, 2006, p. 33.

18.UCTASLI, M.B., BALA, O., GULL, A., J. Oral Rehabil., 31, 2004, p. 1197.

19.MUNTEANU, B., ANDRIAN, S., URSU, L., STOLERIU, S., IOVAN, G., GHIORGHE, C.A., PANCU, G., NICA, I., I.J.M.D., 6, no.3, 2016, p. 124. 20.HELVATJ OGLOU-ANTONIADI, M., PAPADOGIANIS, Y., KOLINIOTOUKUBIA, E., KUBIAS, S., J. Prosthet. Dent., 65, 1991, p. 215.

21.J ONIOT, S.B., GREGOIRE, G.L., AUTHER, A.M., ROQUES, Y.M., Oper. Dent., 25, 2000, p. 311.

22.STANFORD, W.B., FAN, P.L., WOZNIAK, W.T., STANFORD, J,W., J. Am. Dent. Assoc., 110, 1985, p.211.

23.LIM, C.C., NEO, J., YAP, A., J. Oral Rehabil., 26, 1999, p. 48. 24.CHINELATTI, M.A., THOMAZATTI CHIMELLO, D., PEREIRA RAMOS, R., PALMA-DIBB, R.G., J. Appl. Oral Sci., 14, no. 3, 2006, p.188.
25.VENTURINI, D., CENCI, M.S., DEMARCO, F.F., CAMACHO, G.B., POWERS, J.M., Oper Dent., 31, 2006, p. 11.

26.YAP, A.U., MOK, B.Y., Oper. Dent., 27, 2002, p. 161.

27.SCHMIDLIN, P.R., GOHRING, T.N., Oper Dent, 29, 2004, p. 80. 28.PATEL, B., CHHABRA, N., JAIN, D., J. Conserv. Dent., 19. no. 1, 2016, p. 37.

29.ENDO, T., FINGER, W.J ., KANEHIRA, M., UTTERODT, A., KOMATSU, M., Dent. Mater. J., 29, 2010, p. 213.

30.ERGUCU Z., TÜRKÜN, L.S., Oper. Dent., 32, no.2, 2007, p. 185.

31.EFREIFEJ, N.S., OWEIS, Y.G., ELIADES, G., Oper. Dent., 38, no.1, 2013, p. 9.

32.KAKABOURA, A., FRAGOULI, M., RAHIOTIS, C., SILIKAS, N., J. Mat. Sci. Mater. Med., 18, no.1, 2007, p.155.

33.BASEREN, M., J. Biomat. App., 19, no.2, 2004, p. 121.

34.ANDRIAN, S., MUNTEANU, B., TARABOANTA, I., NEGRAIA, D., NICA, P.E, STOLERIU, S., NICA, I., E-Health and Bioengineering Conference, 2017, 978-1-5386-0358-1/17

35.BACIU, E.R., BEN AMOR, H., CALAMAZ, D., BACIU, M., GRADINARU, I., Rom. J. Oral Rehabilit., 8, no. 3, 2016, p. 19

Manuscript received: 18.07 .2107 